\section{Probit Analysis \\ D. J. FINNEY}

The first text-book on a new branch of statistical study widely used in connection with the biological assay of insecticides, fungicides, drugs, etc. This book, based on experienceat Rothamsted Experimental Station, gives an account of the theory and practice of probit analysis suitable for biologists, chemists and others, with an outline of the underlying statistical methods. Dr F. Tattersfield of Rothamsted contributes an Introduction.

I8s. net

\section{CAMBRIDGE}

UNIVERSITY PRESS
A few MICHROME BRAND

Stains \& ReAGENTS FOR MICROSCOPY
Auramine

Azur I \& II

Chicago Blue

Cedarwood Oil

Celloidin

Evans Blue

Field's Stain

Giemsa Stain

Haematoxylin

Indigo Carmine

Leishman Stain

May Grunwald etc.
Nile Blue

Pontamine Sky Blue

Purpurin

Rosolic Acid

Ruthenium Red

Sudan I, II, III \& IV

Thioflavine $\mathrm{T}$

Titan Yellow

Toluidine Blue

Trypan Blue

Vital Red

Wright's Stain etc.
Price List on application

\section{EDWARD GURR LTD.} 108 WATERFORD ROAD

WALHAM GREEN, LONDON, S.W.6

Tel. : Renown 201 r Cables: Gurr, Renown 2011 , London

FOR IMMEDIATE DELIVERY

UNIFORM HIGH QUALITY AND RELIABILITY StIPULATE

MICHROME BRAN

\title{
The TREMATODA
}

\section{BEN DAWES}

A detailed study of the trematode parasites of vertebrate animals such as the advanced student of zoology dissects in the laboratory, intended to give zoologists and parasitologists a more useful account of the Trematoda than can be found in existing works. The author is Lecturer in Zoology at King's College, London.

$$
\text { s2s. } 6 \text { d. net }
$$

\section{CAMBRIDGE UNIVERSITY PRESS}




\section{O N T E N T S}

\section{(All rights reserved)}

Hobson, A. D. The physiology and cultivation in artificial media of nematodes parasitic in the alimentary tract of animals . . . .

REes, GWEndoten. A study of the effect of light, temperature and salinity on the emergence of Cercaria purpurae Lebour from Nucella lapillus (L.). (With 13 Figures in the Text)

TURK, Frank A. On two new species of tiek. (With 11 Figures in the Text)

Hetsoh, R. B. and Garnham, P. C. C. The transmission of Spirochaeta duttoni Novy \& Knapp by Pediculus humanus corporis de Geer . .

SHARIF, M. Nutritional requirements of flea larvae, and their bearing on the specific distribution and host preferences of the three Indian species of Xenopsylla (Siphonaptera)

ShuTe, P. G. and Maryon, M. The gametocytocidal action of paludrine upon infections of Plasmodium falciparum . . . . . . 264

INDEX OF AUTHORS.

INDEX OF SUBJECTS .

PARASITOLOGY is published about four times a year. The numbers afterwards are issued in volumes each containing four numbers.

Papers for publication should be sent to Professor D. Krintr, Molteno Institute, Downing Street, Cambridge. Other communications should be addressed to the University Press, Cambridge.

Papers forwarded to the Editors for publication are understood to be offered to PARASITOLOGY alone, unless the contrary is stated.

Contributors receive fifty copies of their papers free. Additional copies, not exceeding one hundred (except in special cases), may be had at cost price: these should be ordered when the final proof is returned.

The subscription price is $£ 2.15 s$. per volume (post-free), payable in advance; single numbers $18 \mathrm{~s} .6 \mathrm{~d}$. net (double number $37 \mathrm{~s}$. net). Subscriptions may be sent to any Bookseller, or to The Cambridge University Press, Bentley House, 200 Euston Road, N.W. 1.

The Cambridge University Press has appointed the University of Chicago Press agent for the sale of Parasitology in the United States of America.

Printed in Gredt Britgin at the University Press, Cambridge

(Broole Crutthlej, Oniversity Printer) 